\title{
Angels as arguments? The rhetorical function of references to angels in the Main Letters of Paul
}

\begin{abstract}
Author:
D. Francois Tolmie

Affiliation:

${ }^{1}$ Faculty of Theology, University of the Free State, South Africa

Note:

This article is a revised version of a paper read on 24 August 2009,

at a meeting of the International Colloquium on the New Testament at the University of Pretoria. It is based upon work supported by the National Research Foundation of South Africa.
\end{abstract}

Correspondence to: Francois Tolmie

email:

tolmief@ufs.ac.za

Postal address:

PO Box 339, Bloemfontein 9300, South Africa

Dates:

Received: 08 April 2010 Accepted: 30 July 2010 Published: 07 June 2011

How to cite this article: Tolmie, D.F., 2011, 'Angels as arguments? The rhetorical function of references to angels in the Main Letters of Paul', HTS Teologiese Studies/ Theological Studies 67(1), Art. \#825, 8 pages. DOI: $10.4102 /$ hts.v67i1.825

(C) 2011. The Authors. Licensee: OpenJournals Publishing. This work is licensed under the Creative Commons Attribution License.
The issue investigated in this article is the rhetorical function fulfilled by the references to angels in the Main Letters of Paul. For this purpose all the references to angels in Galatians, 1 and 2 Corinthians and Romans are investigated systematically and thoroughly. This study shows that Paul never uses any of the references to angels as a main argument in these letters. Furthermore, it is shown that Paul refers to quite a variety of (possible) roles that angels might fulfil, or characteristics that angels possess. From a rhetorical perspective, it is evident that Paul mostly mentions angels in contexts that can broadly be typified as hyperbolic - in the sense that the extent or broad scope of the issue under discussion is emphasised.

\section{Introduction}

The theme of angels and/or heavenly powers in the New Testament and in Pauline literature, in particular, has received a fair amount of attention from scholars thus far (cf. for example, Dibelius [1909], Bietenhard [1951], Caird [1956], Schlier [1958], Miranda [1961], Carr [1981], Benoit [1983] and Wink [1984]). In general, such investigations aim to present a broad overview of New Testament or Pauline views on these matters. In contrast to such an approach, the aim of this study is much more modest. The focus will merely fall on the references to angels in the four Main Letters of Paul; this subject will be approached from a particular angle, namely that of rhetorical function. The issue that is to be investigated may thus be formulated as follows: which rhetorical function is fulfilled by the references to angels in Paul's Main Letters?

\section{Angels in the Letter to the Galatians}

In the Letter to the Galatians, angels are mentioned in three passages. The first instance is found near the very beginning of the letter, in Galatians 1:8 - part of a section that can be delimited as Galatians 1:6-10. In this section, Paul expresses his extreme disgust at the events in the Christian churches in Galatia, thereby attempting to persuade the Galatian Christians to reconsider what they are doing. He uses very forceful techniques to convey his intense feelings, namely:

- a rebuke in verse 6

- vilification of his opponents in verses $6 c-7$

- a twofold curse in verses 8-9

- rhetorical questions in verse 10 .

Of these, the twofold curse ${ }^{1}$ in verses $8-9$ is of special interest for this investigation, because Paul refers to 'an angel' when he invokes this curse:

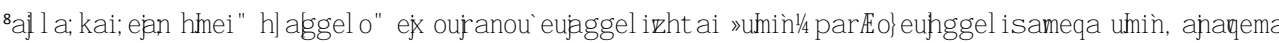

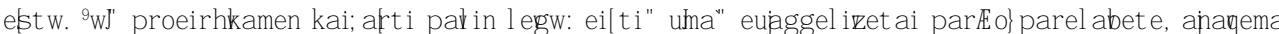
ekt w. [ ${ }^{8}$ But even if we or an angel from heaven should proclaim to you a gospel contrary to what we proclaimed to you, let that one be accursed! ${ }^{9}$ As we have said before, so now I repeat, if anyone proclaims to you a gospel contrary to what you received, let that one be accursed! $\left.{ }^{2}\right]$

The careful way in which this curse is structured has often been noted. In verse 8, Paul uses an ea n [if]-eventualis, ${ }^{3}$ thereby indicating an unreal situation: ${ }^{4}$ neither he ${ }^{5}$ nor an angel would actually proclaim a gospel contrary to that which he has proclaimed to the Galatians. In verse

1.In ancient rhetoric, the effectiveness of using a curse was often noted. Cf. for example, the discussion by Betz (1979:45-46).

2.All translations from New Revised Standard Version, except where indicated otherwise.

3.The reading in Nestle-Aland $27^{3}$ has been followed here.

4.Cf. Blass-Debrunner-Rehkopf §373.2: ‘ej a [if] mit Konj. ... vereinzelt statt Irrealis'. Cf. also §373.1.11: 'Unbestimmte Beziehung auf die vorliegende Wirklichkeit: 1 Kor 4,15 ea n gar mur iou" paidagwgou" ef ht e [For though you might have ten thousand guardians in Christ] "wenn ihr auch haben solltet“ (klass. potential oder irreal)'. This example is similar to the one that is encountered in Galatians $1: 8$. Cf. also 1 Corinthians 13:1-3.

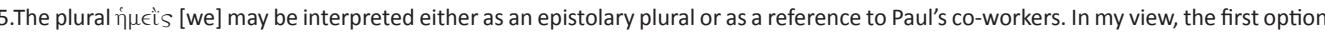
is more plausible. Cf. Mussner (1977:59, n. 84). 
9, on the other hand, an el' [if]-realis ${ }^{6}$ is used. This change is usually interpreted as an indication of a progression from the hypothetical situation indicated in verse 8 - which according to Paul was inconceivable, because neither he nor an angel would proclaim a different gospel - to the concrete situation that prevailed at the time in Galatia, where Paul's opponents were doing exactly that. See, for example, Burton (1962):

V. 8: The clause, so far as hmei" h] aggel o" ej ouj anou' [we or an angel from heaven] is concerned, is concessive, being unfavourable to the fulfilment of the apodosis... It is, of course, only rhetorically a possibility.

(Burton 1962:25)

V. 9: The form of the condition that suggests future possibility is displaced by that which expresses simple present supposition, and which is often used when the condition is known to be actually fulfilled. The result is to bring the supposition closer to home to the actual case ...

(Burton 1962:30)

What is the rhetorical function of this reference to an angel? To my mind, three aspects are important. Firstly, the reference to an angel creates a 'hyperbolic' effect in the sense that it forcefully conveys to the audience ${ }^{8}$ the wide scope covered by the curse - literally anyone is included; if even angels are included, then no one will be spared. This effect is heightened by Paul's use of a I a ; ka i [even if] at the beginning of verse 8 . Secondly, the fact that Paul dares to curse an angel indicates to the audience - in a striking way - how absolutely sure he is that his views are correct. Take note that he specifically refers to the angel as 'an angel from heaven', thereby indicating that he has a good angel in mind, a heavenly messenger. Lastly, the subtle way in which Paul places himself in 'high' company should not go unnoticed. He mentions himself and an angel from heaven together, so to speak, in one breath. He thereby implies that he himself and such an angel would act in a similar way, thus suggesting that, like the angel, he is obedient to God.

The second reference to angels is found in Galatians 3:19, a verse that forms part of the section comprised in 3:19-25. As there is consensus amongst scholars on Paul's rhetorical strategy in this section, at least to a large extent, I will only provide a brief overview in this regard. ${ }^{9}$ Paul seemingly uses this section to explain the function of the law. Apparently, he realises that what he has said thus far in the letter about the law might make the audience wonder why God gave the law at all, if it does not seem to have any positive function. Therefore, he now indicates that he intends to address the

6.Lambrecht (1987:153-156) provides a brief but cogent overview of Paul's use of conditional sentences.

7.Amongst others, see also Lightfoot (1921:77), Mussner (1977:60), Behnisch (1984:245-247), Morland (1995:148-149), Kremendahl (2000:83) and Longenecke (1990:16-18). However, not everyone agrees that verse 8 indicates a hypothetical situation. For example, Betz $(1979: 53)$ believes that the point was precisely to envision the seemingly unthinkable', whereas Martyn (1997:113) assumes that Pau is referring to his opponents in Galatia - and that these opponents had actually claimed that an angel was speaking through them, thereby proclaiming the gospe to the whole world - hence the reference to an angel. However, if this were indeed the case, one would expect Paul to have spent more time elaborating on the matter, rather than making a mere brief reference at the beginning of the letter.

8.The term 'audience' is used to include both readers and listeners (with the original context in mind).

9.For a more detailed discussion of what follows, see Tolmie (2005:131-142). purpose of the law. However, he then proceeds to discuss this issue in such a way that the inferiority of the law, in comparison to the promises of God or faith, is emphasised. In verses 19-20, he begins by means of a rhetorical question (t i voun olnomo" ; [Why then the law?]), which is then followed by a series of concise statements:

t wh̀ parabasewn carin proset eqh, acri" oule[ qh/to; sperma wl ephggeltai, diatagei" di Faggetrwn en ceiri;mesitou.

[It was added because of transgressions, until the offspring would come to whom the promise had been made; and it was ordained through angels by a mediator.]

For our purposes, two aspects should be noted. Firstly, from a rhetorical perspective, it is important to realise that Paul lumps together a number of characteristics of the law that, as such, do not automatically imply its inferiority. However, within this context, he deliberately contrasts some of these aspects with the oneness of God, thereby suggesting the notion of the inferiority of the law. In this regard, the notion that the law 'was ordained by angels' is a good example. In itself, this does not necessarily imply that the law is inferior; in fact, it could be viewed as being indicative of the importance of the law. However, within this context it is clear that Paul views the matter in a different light: ${ }^{10}$ from (the notoriously difficult) verse 20 (o)de;mesith" eho" ouk est in, olde;qeo" eil" est in [And the mediator is not of one, but God is one - author's translation]), it can be inferred that the notion that the law was ordained through angels is not regarded by Paul as being indicative of its importance. Rather, in his view, it implies that the law was given by means of mediation, whereas the promise came directly from God. This he interprets as indicative of the inferiority of the law, because for him the way in which the promise was given corresponds to the nature of God and in particular, to his oneness, whereas the giving of the law does not. Rhetorically, the reference to the involvement of angels is thus used by Paul to emphasise the inferiority of the law.

Secondly, there is some debate on the nature of the angels whom Paul has in mind. Most scholars assume that he is referring to good angels, but this is disputed by Hübner (1980:28-30), who is of the opinion that, according to Galatians 3:19, the law did not come from God, but from evil angels who gave it to humankind in order to provoke them to violate the law. However, Hübner's views cannot be accepted. The most important reason for rejecting his interpretation is that, if Paul had actually thought that evil angels were responsible for the giving of the law, this would have been such an excellent argument against what was going on in Galatia, that one would expect him to have exploited it to a much larger extent in his letter. However, this does not happen at all; the reference to the

10.Paul takes it for granted that his audience is aware of the tradition that God used angels to give the Torah. Many exegetes accordingly accept the widespread existence of such a tradition. However, this has been challenged by, amongst others, Mach (1982:57-70) and Gaston (1982:65-75). Cf. also Najman (2000:313333), who points out three exegetical strategies employed by the rabbis to oppose the notion of angelically mediated revelation: denying it; eliminating the angels; or regarding them as obstacles to be overcome by Moses before he could receive the Torah from God. 
role of angels is restricted to a mere three words. It thus seems logical to accept that Paul has good angels in mind. In fact, it is all but certain that if he were pursuing the idea that the law did not come from God, he would thereby be damaging his rhetorical strategy (as correctly pointed out by Thurén 2000:28-30).

The last reference to angels is found in Galatians 4:1411, part of the section comprised in 4:12-20, which is largely dominated by emotional arguments. The reference to an angel is found in what can be identified as the second segment of the section. ${ }^{12}$ In this segment $(4: 12 c-16)$ Paul uses the Galatians' former behaviour towards him, when he visited them for the first time, as a basis for rebuking them for their current attitude:

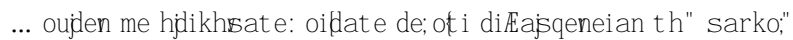
euhgge li samhn umiǹ to; proteron, kai;ton peirasmon umwǹ ej th/sarkivmou ouk exougenhsate oude; exept usate, alla; w' aggel on qeou 'edexas qe me, wj' Crist on jlhsoun.

[... You have done me no wrong. You know that it was because of a physical infirmity that I first announced the gospel to you; though my condition put you to the test, you did not scorn or despise me, but welcomed me as an angel of God, as Christ Jesus.]

For our purposes, two aspects should be noted: firstly, in this instance the reference to an angel (who, it must be pointed out, is specifically described as an angel 'from God') is used rhetorically to create a hyperbolic portrayal of the Galatians' (former) positive attitude towards Paul. Instead of merely saying that they accepted him gladly during his visit, their behaviour is portrayed in terms of the way in which humans normally acted towards angels. ${ }^{13}$ In fact, the hyperbole is even taken one step further in the next phrase ('like Christ Jesus'). Secondly, it is also important to keep the broader background in mind. Paul was ill when he visited the Galatians for the first time; and illness was frequently interpreted as a sign of demonic possession. Ill people were therefore often avoided. This 'normal' behaviour is contrasted with the way in which the Galatians acted towards him on that occasion. As Dunn (1995:234) puts it: 'Instead of regarding Paul as a tool or victim of demonic possession, they had realized that he came with God's message, that is, as one sent from God'. This hyperbole then serves as a basis for the rebuke that follows: how their attitude towards him has not changed in the meantime! In other words, the more their former behaviour towards him is amplified, the more appalling their current behaviour toward him appears.

\section{Angels in the Letters to the Corinthians}

The first reference to angels in the Letters to the Corinthians is found in 1 Corinthians 4:9. In this chapter, Paul admonishes the Corinthians by comparing their blameworthy behaviour

11.Some scholars interpret ta; s t oic eià t ou 'kos mou [the elements of the world own translation] in Galatians 4:3 as referring to demonic forces or angelic beings (cf. Betz 1979:204-205); but, in my view, it is more plausible to interpret it in the sense of 'elementary principles' given by God. Cf. Longenecker (1990:165-166).

12.I divide this section into four segments: $4: 12 a-b$, dominated by Paul's pleading $4: 12 \mathrm{c}-16$, in which the Galatians' former behaviour toward him is used as a basis for rebuking them; 4:17-18, dominated by vilification of his opponent and 4:1920 , in which he expresses his affection and concern for the Galatians.

13.Cf. Betz (1979:226, n. 270) on this 'familiar religious and literary motif'. with that of 'the apostles'. After the ironical portrayal of the Corinthians in verse 8 ('You are already satiated ... have become rich ... have become kings ...'), the suffering of the apostles is depicted in a vivid way and angels are mentioned for the first time in 1 Corinthians: dokw gav, of qeo," hma" tou," apostovou" escatou" apedeixen wj" epiqanatiou", oki qeatron egenhqhmen tw/kosmw/kai; aggevoi" kai; ajgr wpoi" [For I think that God has exhibited us apostles as last of all, as though sentenced to death, because we have become a spectacle to the world, to angels and to mortals]. The metaphor that Paul uses is striking. The connotations of this metaphor are linked to a context $\mathrm{t}^{14}$ in which people were being condemned to die in the arena. Such people were taken there as part of a parade, of which they usually formed the rear part. Thus, Paul portrays the apostles as the 'last'; people who are about to die and of whom a show is being made - a spectacle eagerly being watched by the crowd. By means of this metaphor, Paul claims that the apostles have become a spectacle 'to the universe, and to angels and to people'. What is the rhetorical function of the reference to angels in this case? It seems that, as in some of the instances previously discussed in this study, the reference is employed (together

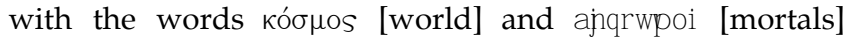
in a hyperbolic fashion - in this instance, to help to create the notion of a cosmic spectacle, thereby underscoring the apostles' suffering, which, in turn, makes the contrast with the Corinthians' shameful behaviour even more striking.

Can anything be surmised with regard to the nature of the angels in this instance? It may be that this aspect is not important in this case and that 'angels' merely function as a counterpart of 'people'. On the other hand, one could develop Paul's metaphor a little further: the fact that crowds normally delighted in the suffering and killing of the victims in the arena ${ }^{15}$ may be projected on to the angels referred to in this instance, thereby creating a not very positive picture of the attitude of the angels towards the suffering of the apostles, which would imply that they are evil angels. However, it should immediately be conceded that there is no clear indication in the text that this nuance of the metaphor is indeed important. In fact, the metaphor makes perfect sense without this notion.

The next reference to angels is found in 1 Corinthians 6:3. Paul mentions angels when he reproaches the Corinthians for taking disputes with each other to Gentile courts instead of consulting other believers in Corinth on such matters. In his reproach he reminds them that the believers will judge the world and, in fact, will even judge angels and then argues that it should thus be easy for them to make decisions on (less

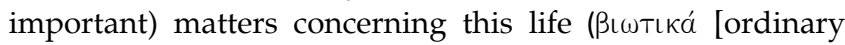
matters]). The reference to angels thus functions rhetorically as part of a climactic argument (world - angels), which in turn

14.For more detailed discussions of the background of this metaphor, refer to, amongst others, Lindemann (2000:106) and Thiselton (2000:359-360).

15.Cf. the overview that Edwards (2007:46-77) presents on 'looking at death in the arena'. In the case of gladiators, the crowds sometimes displayed sympathy and even admiration; but in the case of doomed convicts (noxii), there was little sympathy. Cf. also Kyle (2001:91-95). 
forms the basis of an a maiore ad minus argument (judging the world and angels; judging bi wt i ká [ordinary matters]) which is used to reproach the Corinthians.

The nature of the angels that Paul has in mind is disputed. Many commentators ${ }^{16}$ assume that Paul is referring to evil angels, thus reflecting the theme of the judgement of evil angels which is also found elsewhere in the New Testament, for example, in 2 Peter 2:4 and Jude 6. Meyer (1861:135), however, believes that Paul has only good angels in mind, because the word 'angels' is used without any closer specification ('ohne andere Näherbestimmung'). However, this is not a good argument, because the term 'angels' is used in a similar way in Romans 9:38, where it is likely that Paul is referring to evil angels (cf. the discussion of Romans 9:38 further on in this article). Another possibility is that Paul has in mind both good and bad angels. This is accepted by Barrett (1971:136), who argues that both humans and angels will appear before God's court at the last day and that this implies that both good and bad angels will be judged. Still another option is offered by Cullmann (1962:176), who interprets the passage as a reference to the judgement of the guardian angels ('Völkerengel') of the nations, who are the real powers behind the earthly governments. In deciding on this matter, I concur with Hoskins (2001:287-297), who investigated the Biblical and extra-Biblical parallels to 1 Corinthians 6:3 and argues that it is best to interpret this passage as a reference to the judgement of the fallen angels, because quite a number of parallels can be indicated for this notion, but not for the other options. ${ }^{17} \mathrm{He}$ also correctly points out that the identity of the angels is not the central issue in 1 Corinthians 6:3. Rather, 'what is central is that beings belonging to the class of angels will be judged by the saints' (Hoskins 2001:296).

Determining the rhetorical function of the next reference to angels in 1 Corinthians, namely that in 1 Corinthians 11:10, is not too difficult. From a rhetorical perspective, it is evident that the allusion is used by Paul as (part of the) motivation for instructing Christian women 'to keep control of their heads': ${ }^{18}$ dia; t out 0 of eivei hJgunh; exousian ek ein ep i $t^{\text {" }}$ kef al h" dia;tou," ag gevou" [For this reason a woman ought to have authority on her head, because of the angels - own translation]. In other words, Paul uses it as a motivation in his attempt to control certain patterns of behaviour amongst (some of?) the Christian women in Corinth. However, this is all that can be said with certainty. Unfortunately, the details

16.Cf. Conzelmann (1981:134, n. 122), Collins (1999:232) and Lindemann (2000:136). Thiselton (2000:431) also refers to Chrysostom, Theophylact, Aquinas, Erasmus, Bengel, Theodoret, Erasmus and Calvin in this regard.

17. Hoskins points out that there are no convincing parallels for the idea that good angels will be judged on the last day (contra Barrett) and that Cullmann overstate the evidence by claiming that a widespread Jewish belief existed that all peoples were ruled through angels. In spite of the parallels indicated by Hoskins for the notion of the judgement of the fallen angels, he also rightly stresses the uniqueness of the notion in 1 Corinthians 6:3: 'In 1 Cor 6:2-3 Paul is not merely adapting a common Jewish eschatological belief; he is making, instead, a unique claim that is more closely tied to his Christology and ecclesiology than to his Jewish background' (Hoskins 2001:297).

18.The expression is sometimes translated as 'to have a sign/symbol of authority on their heads', but I prefer to follow scholars who translate it as 'to keep control of their heads' - in the sense of having power over their own heads by wearing their 'hair appropriately, that is, as is fitting in the context of worship' (Collins 1999:411). 'hair appropriately, that is, as is fitting in the context of worshit
For the relevant arguments, cf. Thiselton (2000:838-839). of the argument remain obscure; firstly, because it is difficult to determine exactly what the problem was and secondly, because the cryptic expression dia; t ou" aggevou" [because of the angels] does not provide one with any clues as to the possible role that Paul ascribes to angels. With regard to the first issue, the control that Paul wishes women to exercise over their heads could refer either to the wearing of a veil, to the length of their hair (long hair - as was customary for women - instead of short hair), to hairstyles (keeping their long hair properly bound - as was customary - instead of having it free flowing and hanging down) or to a combination of these options. ${ }^{19}$ The fact that 'an uncovered head' and 'hairstyle' are discussed in close association in verses $13-15$, seems to tilt the scale towards the notion of hairstyles (thus also Klauck 1984:78-79 and Lindemann 2000:241). If this is correct, it means that some of the women in Corinth (perhaps as a result of the newly achieved liberty in Christ ${ }^{20}$ ) participated in the worship services with free-flowing hair, instead of having the required hairstyle. Paul opposes this for two reasons: firstly, in his view, it is in conflict with the customary hierarchical gender-related roles that he links to creation (cf. dia; t out 0 [because of] at the beginning of verse 10). Paul's views in this regard reflect notions that were widespread in antiquity in respect of women and, in particular, women and sexuality, as well as the role that hair played in this regard. ${ }^{21}$ Secondly, ${ }^{22}$ women should keep control of their heads di a ; 0 u," a g g ev ou" [because of the angels]. Various suggestions have been made as to exactly what is meant by this. It has been proposed:

- that Paul refers to fallen angels, lustfully desiring earthly women (thus already Tertullian, Virg. Vel. 7.4-8)

- that he is referring to angels in terms of their role of guardian angels or watchers over the natural order (Foerster 1973:574) or their role as witnesses to creation (cf. Collins 1999:412)

- that angels were regarded as being present during worship meetings as in Qumran (Fitzmyer 1957/58:4658)

- that Paul is alluding to them in terms of their roles as representatives and mediators of prayer and prophecy (Schrage 1991:517).

The fact that Paul refers to the angels within a context in which worship is important, leads me to infer that his warning is in some way related to the notion that angels were present during worship services; believers thus worshipped God in the company of the heavenly host (cf. amongst others,

19.The literature on this matter is extensive. Cf. the overview in Thiselton (2000:823$826)$. I cite only one example from the literature for each of the options outlined above: wearing a veil (Dale Martin 1995:229-249); long or short hair (Gielen 1999:220-249); hair properly bound (Klauck 1984:78-79); combination of long or 1999:220-249); hair properly bound (Klauck 1984:78-79)
short hair and wearing a veil (Conzelmann 1981:224).

20.Thus, many scholars. However, some scholars link this practice amongst Christians to other influences, for example, to contemporary pagan traditions (Troy Martin 2005:264).

21.See, in this regard, Dale Martin (1995:229-249) and Troy Martin (2004:75-84).

22.In concurrence with, for example, Lindemann (2000:244), I assume that Si⿳亠口冋 to ou a g gevou" [because of the angels] indicates a second and thus an additional motivation and that it is not a further development of the notion introduced by $\delta i \dot{\alpha}$ t out 0 [because of] (which refers to the verses preceding verse 10). If this is not the $t$ out 0 [because of] (which refers to the verses preceding verse 10). If this is not the
case, the reference to angels should be linked to creation in some way, for example in terms of the fact that they were witnesses of creation (cf. Collins 1999:412); in terms of the fact that they were witnesses of creation (cf. Collins 1999:412);
or otherwise, it could be assumed (to my mind, erroneously) that Paul attributes or otherwise, it could be assumed (to my mind, erroneously) that Paul attributes
the creation of woman from man to angels (proposed by Beduhn 1999:295-320). 
Thiselton 2000:841). If this is correct, Paul's warning may be interpreted in two ways: firstly, he might have been of the opinion that the (good) angels who were present during worship services would be offended by the unbecoming hairstyles of some of the women, because these hairstyles did not reflect typical gender roles (including notions of sexuality). A second option (to my mind less likely) is that Paul was thinking of angels in general. Because angels were commonly understood in terms of male sexuality and always had 'the capacity to violate the cosmic order', becoming hairstyles functioned as a prophylactic measure against them (Stuckenbruck 2001:231)..$^{23}$

The next reference to angels appears in 1 Corinthians $12: 31 b-14: 1 a$, a section devoted to the gift of love as the antidote to factionalism' (Mitchell 1991:270). Angels are mentioned in 1 Corinthians 13:1: Ean tai" gl ws sai" t wh̀ ajar wown I al w kai;t wh agg gevwn, agaphn de;mh;ek w, gegona c al ko," hicwn h]kumbal on a lal a z on [If I speak in the tongues of mortals and of angels, but do not have love, I am a noisy gong or a clanging cymbal]. In verses $1-3$, it is stressed that charismatic gifts without love are worthless. From a rhetorical perspective, the reference to angels in verse 1 again functions hyperbolically and is constructed in a climactic fashion: 'If I speak in the tongues of humans and (even) of angels ...'. The effect of the reference to the tongues of angels is thus hyperbolic, helping to underline the notion of how extremely important the gift of love is. The allusion to the tongues of angels (in this instance, it may be taken for granted that good angels are referred to) presupposes that angels have their own language $\mathrm{e}^{24}$ and although it makes good sense to interpret the phrase as merely referring in general to a contrast between human and angelic languages (cf. Sigountos 1994:252-253), the context suggests that something more is on Paul's mind, namely the fact that speaking in tongues might be regarded by some of the Corinthians as speaking the heavenly, angelic language (Thiselton 2000:1033; Martin 1995:267, n. 263). If this is indeed the case, he is not merely contrasting the gift of speaking human and angelic languages with that of love; rather, he is contrasting speaking in tongues with the gift of love.

In 2 Corinthians angels are mentioned only twice. In 2 Corinthians 11:13-15 Paul accuses the 'false apostles' of disguising themselves as apostles of Christ. In 2 Corinthians 11:14 this behaviour is linked to that of Satan, who also disguises himself as 'an angel of light':25 a ut. 0" gar 0 f satana" met aschmatizetai ei]" aggel on f wt o" [Even Satan disguises himself as an angel of light]. The notion that Satan could disguise himself is also reflected in other sources: in

23. Here, I have slightly adapted Stuckenbruck's views, in the sense that he interprets this section in the Corinthian correspondence as referring to the wearing of veils, whereas I interpret it as referring to hairstyles. However, in both cases the prophylactic function would be similar. According to Stuckenbruck, a veil was regarded as protective in two respects: 'On the one hand, it protects the woman against inadmissible invasions from the outside and, on the other hand, protects those on the outside (so, from the male point of view!) against vulnerability to evil that the woman represents' (Stuckenbruck 2001:232).

24.For a discussion of the language of angels presupposed in 1 Corinthians 13:1, cf. Klauck (2000:277-284).

25.As Harris (2005:774) points out, the Greek expression can be translated in different ways: A messenger from God; a messenger of (the world of) light; a shining angel; or an angel of light. I prefer the last option, in the sense of an angel characterised by light. the Testament of Job he disguises himself as a beggar (6:4), the Persian king (17:2), a whirlwind (20:5) and a bread-seller (23:1); in the Life of Adam and Eve he changes himself into the brightness of angels and in the Apocalypse of Moses he adopts the form of an angel (cf. Harris 2005:774 for more details). In 2 Corinthians 11:14, 'angel of light' rhetorically serves as the direct opposite of 'Satan', thus indicating the total difference between appearance and reality. In verse 15 Paul then applies this notion to the 'false apostles' who, as 'Satan's servants', do the same things as Satan does. This verse thus contains an example of extreme vilification.

In the next chapter, an angel is mentioned again. This angel is also linked to Satan, but whereas the angel of chapter 11 was a good angel, the one mentioned in 2 Corinthians 12:7 is obviously an evil angel: dio; ina mh; uperairwma $i$, ejogh moi skovoy th' sarkivaggelo" satana; ina me kolafiv $\mathrm{zh} / \mathrm{i}$ ha mh; uperairwmai [Therefore, to keep me from being too elated, a thorn was given to me in the flesh, an angel of Satan, to torment me, to keep me from being too elated - own translation]. The expression aggel o" sat ana' [angel of Satan] is in an appositional relation to skovoy [thorn], thus identifying skovoy [thorn] as aggel o" sat a na' [angel of Satan] (Lambrecht 1999:203). Normally scholars focus on the identification of the 'thorn' ${ }^{26}$ but for our purposes the rhetorical function of the reference to 'an angel of Satan' is important. What is rhetorically achieved by this? To my mind, it primarily serves as a way to emphasise the intensity of the affliction caused by the 'thorn'. ${ }^{27}$ If Paul had only mentioned a 'thorn in the flesh', one might perhaps have thought of something painful, but still relatively bearable. The expression 'an angel of Satan to torment ${ }^{28} \mathrm{me}^{\prime}$ removes any doubt as to the intensity of the affliction.

\section{Angels in the Letter to the Romans}

In the Letter to the Romans, angels are mentioned only once, namely in Romans 8:38. ${ }^{29}$ This verse forms part of the section comprised in 8:31-39, which forms the climax of Romans $5-8 .^{30}$ Towards the end ${ }^{31}$ of this 'purple passage of praise' (Dunn 1998:492), Paul expresses his confidence ${ }^{32}$ that nothing will ever be able to separate believers from God's love. This

26. Harris (2005:858-859) provides a good overview of proposals that have been made in this regard. He divides these proposals into three broad categories: Spiritual or psychological anxiety, opposition to Paul and physical malady.

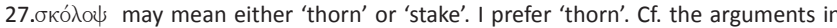
Harris (2005:854).

28.BAGD explains the meaning of $\mathrm{kol}$ a $\mathrm{i} \mathrm{i} \mathrm{W}$ as follows: 'to cause physical impairment, torment ...

29.In Romans 8:38-39 three terms are used to refer to supernatural beings: a g g el $0 \mathrm{i}$ [angels], aj caiv [rulers] and dunamei" [powers]. Some scholars believe that exous i [ [authority] and a [ c ont e" [rulers] in Romans 13:1-3 include angelic authorities, but this seems unlikely. Cf. the discussion by Jewett (2007:787-789).

30.Cf. Lohse (2003:254) and Jewett (2007:532). This section may even be viewed as the climax of the whole letter up to this point. Cf. Dunn (1998:498-499). Cf. also Tobin (2004:316-317), who points out that Romans 8:38-39 also looks forward to the end of Romans 11.

31.Most scholars prefer to divide the passage into five sections, namely $31 \mathrm{a}, 31 \mathrm{~b}-32$ 33-34, 35-37, 38-39. Cf. Cranfield (1975:442) and Fitzmyer (1993:529). Other proposed divisions include the following: 31a, 31b-32, 33, 34, 35-37, 38-39 (Schmithals 1988:307); 31-34, 35-39 (Balz 1971:117); 31-32, 33-39 (Schreiner

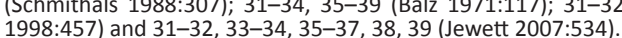

32. $\pi \epsilon ́ \pi \epsilon \iota \sigma \mu a L$ [I am convinced] is in the perfect passive and can be rendered in translation as 'have become convinced', with the implication that the conviction continues into the present. Cf. Jewett (2007:550) for more examples. 
is vividly illustrated by means of the rhetorical technique of enumeratio, which is employed to list ten items - eight of which are grouped in pairs:

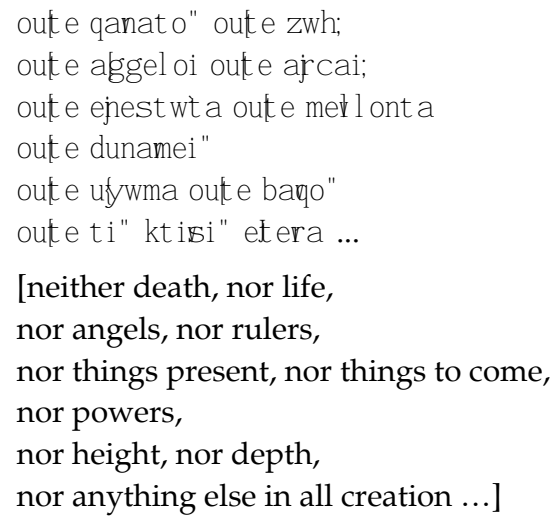

The list is comprehensive: neither death nor life (usually interpreted as a reference to the dangers of this life ${ }^{33}$ ), nor angels nor rulers, neither things present nor things to come (i.e. 'the present age with its instability and any future age with its uncertainty' - Fitzmyer 1993:535), nor powers (usually interpreted as heavenly powers ${ }^{34}$ ), neither height nor depth (which could be interpreted either as astronomical term $\mathrm{s}^{35}$ or in a more metaphoric sense as referring to anything high or low in creation ${ }^{36}$ ), nor any other creature will be able to separate believers from the love of God which is in Christ Jesus. For the purposes of this investigation, the second pair, ouf e a g g el oi ouf e aj cal' [nor angels nor rulers], is of interest. The term a j c a i vrulers] is also used in 1 Corinthians 15:24 (cf. also Col. 1:16, 2:10, 15 and Eph. 1:21), where it refers to hostile heavenly powers; and this is the way in which it is usually interpreted in Romans 8:38, too. ${ }^{37}$ Together the two concepts in the pair thus refer to superhuman beings or powers who might attempt to separate believers from the love of God. With specific regard to Paul's reference to 'angels', two further remarks should be made. Firstly, rhetorically speaking, the reference again occurs in a 'hyperbolic' context, not in the sense that Paul did not actually believe that these forces might threaten believers, but in the sense that all the sources of danger referred to in the list are extreme dangers in nature (cf. the peristasis catalogue in v. 35). In this instance, the rhetorical purpose of the reference to angels (together with the rest of the list and the peristasis catalogue) is to encourage the readers: whatever might threaten them, they will never be separated from the love of God. Secondly, the nature of the angels is not indicated. This leaves one with three options: Paul might have deliberately left the question open, because he has in mind any kind of angel, good or

33.Cf. Fitzmyer (1993:535) and Cranfield (1975:442).

34.Cf. Dunn (1998:507), Lohse (2003:260) and Jewett (2007:553).

35.Cf. Dunn (1998:507-508).

36.Cf. Schreiner (1998:465-466).

37.In fact, most commentators interpret Romans 8:38 in this way. I am aware of one exception. According to Jewett (2007:552), who refers to Barrett's interpretation
of ápxaıv[rulers] in 1 Corinthians 15:24, it seems likely that in Romans 8:38 the term refers to political rulers. However, to my mind, the fact that $\alpha \gamma \gamma \gamma \in \lambda$ or [angels]

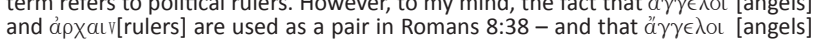
clearly refers to heavenly beings - makes it unlikely that the other term would refer to earthly rulers. Also take note that Barrett (1984:174) does not interpret ápxaiv to earthly rulers. Also take note that Barrett (1984:174) does not interpret $\alpha \rho x$ Xiv
[rulers] in Romans 8:38 as referring to political rulers, but rather as referring to [rulers] in Romans 8:38 as re
'their (= the angels') princes'. evil - in line with the hyperbolic nature of the passage (cf. e.g. Wink 1984:49). The other options are that he is referring to either good (cf. e.g. Schmithals 1988:316) or evil (cf. e.g. Jewett 2007:552) angels. A case could be made out for each of these options; but, to my mind, it is difficult to accept that Paul would assume that good angels would try to separate believers from God's love. It is therefore probable that he has only evil angels in mind. Some scholars refer to Galatians 1:8 in this regard, according to which good angels might act against God's will. However, as I indicated earlier on, in the case of Galatians 1:8, an éáv [if] -eventualis is employed, indicating the impossibility of such a situation, which means that this verse cannot be cited as a parallel to Romans 8:38.

\section{Conclusion}

What insights has this investigation yielded with regard to the rhetorical function of references to angels in the Main Pauline Letters? In general, it is evident that Paul believed in the existence of angels - good and evil. If my analysis is correct, most of the references are to good angels (Gl 1:8; $3: 19 ; 4: 14 ; 1$ Cor 11:10; 13:1; 2 Cor 11:14), with evil angels only referred to or implied in four instances (1 Cor 4:9; 6:3; 2 Cor 12:7; $\mathrm{Rm} 8: 38)$. Of all the instances included in this classification, the interpretations of the references to angels in 1 Corinthians $4: 9$ and 11:10 are the most uncertain.

If we turn our attention to the rhetorical function of angels in Paul's arguments, it should be noted at the outset that the references to angels are never used as a main argument in any section of these letters. Rather, angels are mentioned relatively seldom and when they are, in fact, alluded to, one does not find any extensive discussion of them or any detailed argumentation based on them. Instead, they are merely mentioned briefly; in some instances, the references might even appear incidental. Closer investigation of the rhetorical function of the references to angels revealed quite a variety of (possible) roles that angels might fulfil, or characteristics that angels possess:

- they might proclaim a gospel (G1 1:8)

- the law has been ordained through them (G1 3:19)

- people respond positively to angels (Gl 4:17)

- angels are spectators watching the suffering of the apostles (1 Cor 4:6)

- $\quad$ angels will be judged by believers (1 Cor 6:3)

- when believers take part in worship services, they are in the presence of angels (1 Cor 11:10)

- $\quad$ angels have their own language (1 Cor 13:1)

- an ostensible angel of light might actually be Satan in disguise (2 Cor 11:14)

- one of Satan's angels was sent to torment Paul (2 Cor 12:7).

From a rhetorical perspective, it seems as if Paul mostly mentions angels in contexts that can broadly be typified as hyperbolic, in the sense that the extent or broad scope of the issue is emphasised:

- in Galatians 1:8 the reference to an angel enables Paul to depict the broad scope of the curse that he utters

- in Galatians 4:14 the reference is used to create a 
hyperbolic portrayal of the Galatians' former behaviour towards him

- in 1 Corinthians 4:9 the allusion to angels helps to convey the notion that the apostles' suffering is actually a cosmic spectacle

- in both 1 Corinthians 6:3 and 13:1 angels are referred to as part of a climactic argument (judging the world and even angels and speaking the tongues of humans and even angels respectively)

- in 2 Corinthians 12:7 the intensity of Paul's affliction is emphasised by the reference to an angel of Satan tormenting him

- in Romans 8:38 a reference to angels helps to convey the comprehensive nature of the forces that might attempt (unsuccessfully) to separate believers from God's love.

Apart from their hyperbolic usage, references to angels also function rhetorically in other ways:

- in Galatians 3:19 the role of the angels in the giving of the law is (surprisingly?) used by Paul as an indication of the inferiority of the law

- in 1 Corinthians 6:3 the fact that believers will judge angels is used in an a maiore ad minus fashion to reproach the Corinthian Christians for taking minor matters to Gentile courts

- in 1 Corinthians 11:10 the presence of angels during worship services is used as the motivation for a warning to women to 'control their heads'

- in 2 Corinthians 11:14 a reference to an angel functions as part of the vilification of Paul's opponents.

To return to the question in the title of this article: does Paul use angels as arguments? The answer? Only rarely, but when he does, he does so in a variety of ways, which in some cases, are very complex.

\section{Acknowledgement}

It is a privilege to dedicate this article to Prof. Andries van Aarde for his contribution to New Testament Studies over several decades.

\section{References}

Balz, H.R., 1971, Heilsvertrauen und Welterfahrung: Strukturen der paulinischen Eschatologie nach Römer 8,18-39, Chr. Kaiser, Munich. (BEvTh 59.)

Barrett, C.K., 1971, A commentary on the First Epistle to the Corinthians, Black, London. (BNTC.)

Barrett, C.K., 1984, A commentary on the Epistle to the Romans, Adam \& Charles, London. (BNTC.)

Bauer, W., Arndt, W.F., Gingrich, F.W. \& Danker, F.W., 2000, A Greek-English lexicon of the New Testament and other early Christian literature, University of Chicago Press, Chicago.

Beduhn, J.D., 1999, “'Because of the angels”. Unveiling Paul's anthropology in 1 Corinthians 11', Journal of Biblical Literature 118, 295-320. doi: 10.2307/3268008

Behnisch, M., 1984, 'Fluch und Evangelium. Galater 1,9 als ein Aspekt paulinischer Theologie', Berliner Theologische Zeitschrift 1, 241-253.

Benoit, P., 1983, 'Pauline angelology and demonology. Reflexions on the designations of the heavenly powers and on the origin of angelic evil according to Paul', Religious Studies Bulletin 3, 1-18.

Betz, H.D., 1979, Galatians: A commentary on Paul's Letter to the Galatians, Fortress, Philadelphia. (Hermeneia.)

Bietenhard, H., 1951, Die himmlische Welt im Urchristentum und Spätjudentum, Vandenhoeck \& Ruprecht, Tübingen. (WUNT 2.)

Blass, F., Debrunner, A. \& Rehkopf, F., 2001, Grammatik des neutestamentlichen Griechisch, Vandenhoeck \& Ruprecht, Göttingen.
Burton, E. de W., 1962, A critical and exegetical commentary on the Epistle of the Galatians, T \& T Clark, Edinburgh. (ICC.)

Caird, G.B., 1956, Principalities and powers: A study in Pauline theology, Clarendon, Oxford.

Carr, W., 1981, Angels and principalities: The background, meaning and development of the Pauline phrase hai archai kai hai exousiai, Cambridge University Press, Cambridge. (SNTS.MS 42.) doi: 10.1017/СBO9780511554896

Collins, R.F., 1999, First Corinthians, Liturgical Press, Collegeville. (Sacra Pagina 7.)

Conzelmann, H., 1981, Der erste Brief an die Korinther, Vandenhoeck \& Ruprecht, Göttingen. (KEK V.)

Cranfield, C.E.B., 1975, A critical and exegetical commentary on the Epistle to Romans, vol. 1, T \& T Clark, Edinburgh. (ICC.)

Cullmann, O., 1962, Christus und die Zeit: Die urchrisliche Zeit- und Geschichtsauffas sung, EVZ, Zürich.

Dibelius, M., 1909, Die Geisterwelt im Glauben des Paulus, Vandenhoeck \& Ruprecht, Göttingen.

Dunn, J.D.G., 1995, The Epistle to the Galatians, Hendrickson, Peabody. (BNTC.)

Dunn, J.D.G., 1998, Romans 1-8, Word Books, Dallas. (WBC 38a.)

Edwards, C., 2007, Death in ancient Rome, Yale University Press, New Haven.

Fitzmyer, J.A., 1957/58, 'A feature of Qumran angelogy and the angels of 1 Cor 11:10', New Testament Studies 4, 48-58. doi: 10.1017/S0028688500011395

Fitzmyer, J.A., 1993, Romans. A new translation with introduction and commentary, Doubleday, New York. (AB 33.)

Foerster, W., 1973, ' $' \hat{\epsilon} \xi$ ov ${ }^{\prime} i^{\prime}{ }^{\prime}$ [Authority], Theological Dictionary of the New Testament 2, 562-574.

Gaston, L., 1982, 'Angels and Gentiles in Early Judaism and in Paul', Studies in Religion $11,65-75$.

Gielen, M., 1999, 'Beten und Prophezeien mit unverhülltem Kopf? Die Kontroverse zwischen Paulus und der korinthischen Gemeinde um die Wahrung der Geschlechtsrollensymbolik in 1Kor 11, 2-16', Zeitschrift für die neutestamentliche Wissenschaft und die Kunde der älteren Kirche 90, 220-249. doi: 10.1515/ zntw.1999.90.3-4.220

Harris, M.J., 2005, The Second Epistle to the Corinthians: A commentary on the Greek text, Eerdmans, Grand Rapids. (NIGTC.)

Hoskins, P.M., 2001, 'The use of biblical and extrabiblical parallels in the interpretation of First Corinthians 6:2-3', Catholic Biblical Quarterly 63, 287-297.

Hübner, H., 1980, Das Gesetz bei Paulus: Ein Beitrag zum Werden der paulinischen Theologie. Zweite erweiterte Auflage, Vandenhoeck \& Ruprecht, Göttingen. (FRLANT 119.)

Jewett, R., 2007, Romans: A commentary, Fortress, Minneapolis. (Hermeneia.)

Klauck, H.-J., 1984, 1. Korintherbrief, Echter, Würzburg. (NEB.)

Klauck, H.-J., 2000, 'Mit Engelszungen? Vom Charisma der verständlichen Rede in 1 Kor 14', Zeitschrift für Theologie und Kirche 97, 276-299.

Kremendahl, D., 2000, Die Botschaft der Form: Zum Verständnis von antiker Epistolografie und Rhetorik im Galaterbrief, Vandenhoeck \& Ruprecht, Göttingen. Epistolografie
(NTOA 46.)

Kyle, D.G., 2001, Spectacles of death in ancient Rome, Routledge, London.

Lambrecht, J., 1987, 'Unreal conditions in the Letters of Paul. A clarification', Ephemerides theologicae Lovanienses 63, 153-156.

Lambrecht, J., 1999, Second Corinthians, Collegeville, Liturgical Press. (Sacra Pagina 8.) doi: 10.2143/ETL.63.1.556365

Lightfoot, J.B., 1921, Saint Paul's Epistle to the Galatians: A revised text with introduction, notes, and dissertations, MacMillan \& Co., London.

Lindemann, A., 2000, Der erste Korintherbrief, Mohr (Siebeck), Tübingen. (HNT 9/1.)

Lohse, E., 2003, Der Brief an die Römer, Vandenhoeck \& Ruprecht, Göttingen. (KEK 4.) Longenecker, R.N., 1990, Galatians, Word Books, Dallas. (Word 41.)

Mach, M., 1982, 'Torah-Verleihung durch Engel', in M. Augustin \& J. Kegler (eds.), Das Alte Testament als geistige Heimat. Festgabe für Hans Walter Wolff zum 70. Geburtstag, pp. 57-70, Peter Lang, Frankfurt am Main. (EHS.)

Martin, D.B., 1995, The Corinthian body, Yale University Press, New Haven \& London. doi: $10.2307 / 3268550$

Martin, T.W., 2004, 'Paul's argument from nature for the veil in 1 Corinthians 11:13-15 A testicle instead of a head covering', Journal of Biblical Literature 123, 75-84.

Martin, T.W., 2005, 'Veiled exhortations regarding the veil. Ethos as controlling proof in moral persuasion (1 Cor 11:2-16)', in T.H. Olbricht \& A. Eriksson (eds.), Rhetoric, ethic, and moral persuasion in Biblical discourse. Essays from the 2002 Heidelberg conference, pp. 255-273, T \& T Clark International, New York \& London. (Emory Studies in Early Christianity 11.)

Martyn, J.L., 1997, Galatians: A new translation with introduction and commentary, Doubleday, New York. (Anchor Bible 33A.)

Meyer, H.A., 1861, Kritisch exegetisches Handbuch über den ersten Brief an die Korinther, Vandenhoeck \& Ruprecht, Göttinten.

Miranda, O.A., 1961, The work and nature of angels according to the New Testament, DTh dissertation, United Microfilms Inc., Princeton.

Mitchell, M.M., 1991, Paul and the rhetoric of reconciliation: An exegetical investigation of the language and composition of 1 Corinthians, Mohr (Siebeck) Tübingen. (HUTh 28.) 
Morland, K.A., 1995, The rhetoric of curse in Galatians: Paul confronts another gospel, Scholars Press, Atlanta. (ESEC 5.)

Mussner, F., 1977, Der Galaterbrief, Herder, Freiburg. (HThK 9.)

Najman, H., 2000, 'Angels at Sinai: Exegesis, theology and interpretive authority', Dead Sea Discoveries 7, 313-333. doi: 10.1163/156851700509977

Schlier, H., 1958, Mächte und Gewalten im Neuen Testament, Herder, Freiburg. (Quaestiones disputatae 3.)

Schmithals, W., 1988, Der Römerbrief: Ein Kommentar, Gütersloher Verlaghaus Gerd Mohn, Gütersloh.

Schrage, W., 1991, Der erste Brief an die Korinther, Benziger, Zurich. (EKK 7.)

Schreiner, T.R., 1998, Romans, Baker Academic, Grand Rapids. (Baker Exegetical Commentary on the New Testament.)

Sigountos, J.G., 1994, 'The genre of 1 Cor 13', New Testament Studies 40, 246-260. doi: $10.1017 / \mathrm{S} 0028688500020580$
Stuckenbruck, L.T., 2001, 'Why should women cover their heads because of the angels?', Stone-Campbell Journal 4, 205-234.

Thiselton, A.C., 2000, The First Epistle to the Corinthians: A commentary on the Greek text, Eerdmans, Grand Rapids. (NIGTC.)

Thurén, L., 2000, Derhetorizing Paul: A dynamic perspective on Pauline theology and the law, Mohr-Siebeck, Tübingen. (WUNT 124.)

Tobin, T.H., 2004, Paul's rhetoric in its contexts: The argument of Romans, Hendrickson, Peabody.

Tolmie, D.F., 2005, Persuading the Galatians: A text-centred rhetorical analysis of a Pauline letter, Mohr-Siebeck, Tübingen. (WUNT 190.)

Wink, W., 1984, Naming the powers: The language of power in the New Testament. The powers, vol. 1, Fortress, Philadelphia. 